\title{
Urgences
}

\section{d'écrire les yeux...}

\section{Micheline Lévesque}

Numéro 15, octobre 1986

Épigraphiques

URI : https://id.erudit.org/iderudit/025307ar

DOI : https://doi.org/10.7202/025307ar

Aller au sommaire du numéro

Éditeur(s)

Urgences

ISSN

0226-9554 (imprimé)

1927-3924 (numérique)

Découvrir la revue

Citer ce document

Lévesque, M. (1986). d'écrire les yeux... Urgences, (15), 40-40.

https://doi.org/10.7202/025307ar

Ce document est protégé par la loi sur le droit d'auteur. L'utilisation des services d'Érudit (y compris la reproduction) est assujettie à sa politique d'utilisation que vous pouvez consulter en ligne.

https://apropos.erudit.org/fr/usagers/politique-dutilisation/
Cet article est diffusé et préservé par Érudit.

Érudit est un consortium interuniversitaire sans but lucratif composé de l’Université de Montréal, l'Université Laval et l'Université du Québec à Montréal. Il a pour mission la promotion et la valorisation de la recherche. https://www.erudit.org/fr/ 


\section{Micheline Lévesque}

le sens a une faim

Hélène Hagan: d'un texte inédit

d'écrire les yeux de lait au plancher répandu le matin des pas qui cherchent cou crayon feuille on dirait mille pattes sur fil du temps hésitent à gagner le large. souffler fort vers cercles de liquide par terre élargit l'oeil se déplace dans deux sens au moins tout voir malgré ma tête qui parle TROP OU PRESQUE résiste à lâcher l'oeuf finira quand même par tomber. après la tête qui siège c'est chair sang os ici et là un chant du signe en notes inégales de bouche m'aventure à glisser sur d'autres mots (le mouvement des mains chaudes). puis si près les doigts lettre l'encre de disparaître encore jusqu'à l'état des choses ne tournent plus cela arrive ma vision du monde d'un coup noire et blanche comme l'absence au bout du fil coupé radical d'écrire. un drap épais jeté par-dessus les yeux de lait donne des mots de tête mais finalement je sais il n'y a qu'à dire oui l'oeuf casse ainsi la couleur prend le temps à mesure. petites gorgées ça revient: table chaise monde autour la peau contre la peau les fruits petits pas la page je retourne corps. avec les mains c'est terrible la page et le corps. 